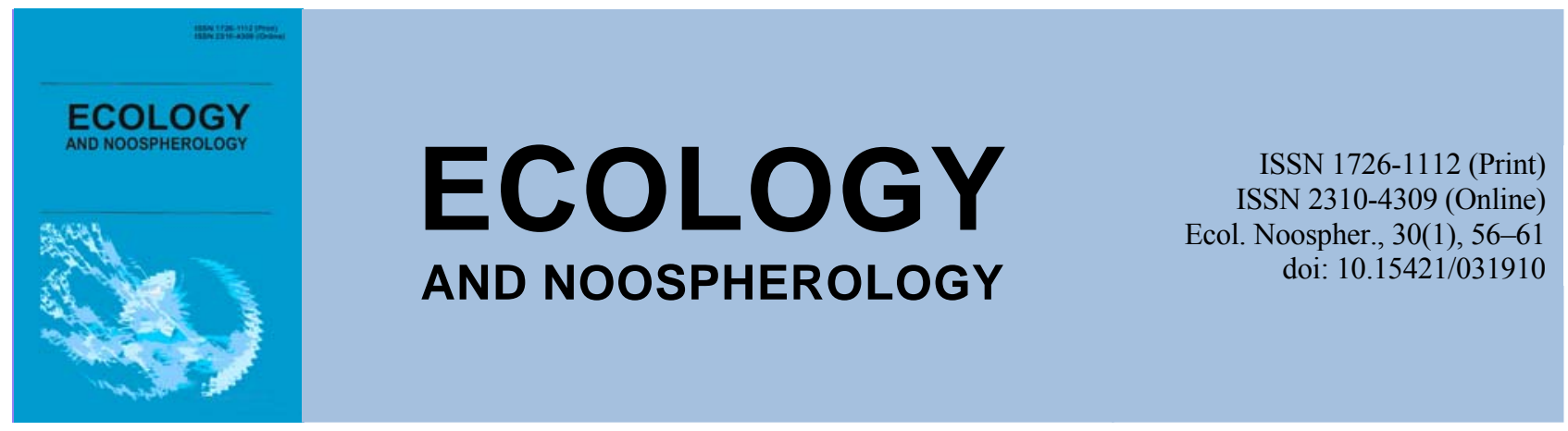

\title{
To ornitofauna of the maniforated forestry of the Kharkov region
}

\author{
V. V. Pesotskaya \\ G. S. Skovoroda Kharkiv National Pedagogical University, Kharkiv, Ukraine
}

Article info

Received 28.01.2019

Received in revised form 08.02 .2019

Accepted 19.02.2019

G. S. Skovoroda Kharkiv National Pedagogical

University,

Alchevsky Str., 29, Kharkiv, 61002, Ukraine.

Tel.: +38-057-717-10-36

E-mail: lerapisocka@ukr.net
Pesotskaya, V. V. (2019). To ornitofauna of the maniforated forestry of the Kharkov region. Ecology and Noospherology, 30(1), 56-61. doi:10.15421/031910

Modern forest belts are a large, complex and important part of the biosphere. The unique biocenoses in which specific ornithocomplexes are formed which include birds of different ecological groups are and feed on synanthropic species, birds of the forest, birds of the fields. The aim of the research is to study the features of the formation of ornithocomplexes of different (mapleash purge forest belts, mixed dense forest belts, acacia purge forest belts, maple-lime openwork forest belts) protective forest belts within the Kharkiv region. In the course of the research we have registered 44 species of birds belonging to 8 rows Falconiformes, Galliformes, Columbiformes, Cuculiformes, Upupiformes, Piciformes, Passeriformes, Ciconiiformes. The formation of ornithocomplexes of protective forest belts depends on various factors. Outstanding is the phytocoenotic composition of forest belts and age structure of plantations. Settling of birds in shelterbelts afforestation occurs gradually, with the growth of trees and change conditions of the biocenosis. The avifauna of maple-ash-tree scavenging forest belts is represented by 39 species of birds. Dominant and subdominant are: ficedula albicollis Temm., Fringilla coelebs L. In mixed shelterbelts purge nest 38 species of birds, is during foraging 2 types. Mixed dense forest belts inhabit 44 species of birds, biodiversity is associated with the floristic composition of the forest belt with significant density and well-formed undergrowth compared to other forest belts. Avifauna gorobinci purge belts are 26 species of birds. Ornithocomplex maple-lime fishnet shelterbelts are 41 species of birds. Analyzing the features of the formation of avifauna of forest belts, it can be argued that these biotopes are inhabited by birds of different ecological groups, biotopes, synanthropic species, birds of the forest, birds of the fields, are able to form unique biotopes. Therefore, field-protective forest plantations combined complex ecosystems. Analyzing the index of similarity of biodiversity of different types of forest belts, it can be argued that the most similar in species composition of birds are mixed dense forest belts and maple-lime openwork forest belts (jacquard Index - 93.1 and Serensen index 96.4) and maple-ash scavenging forest belts with mixed scavenging forest belts (jacquard Index-92.6 and Serensen index 96.2). Determined the relative numbers of registered types for zaplanovano classification V. P. Balka (2009): the most numerous Chaffinch (Fringilla coelebs L.), Zelenyak (Chloris chloris L.), goldfinch (Carduelis carduelis L.), Linnet (Acanthis cannabina L.), song thrush (Turdus philomelos Brehm.), sorokopud of thorns (Lanius collurio L.), Nightingale (Luscinia luscinia L), magpie (Pica pica L.), grey crow (Corvus cornix L.). Rare species are common berestyanka(Hippolais icterina L.), common Buzzard (Buteo buteo L.), common urticaria (Sylvia nisoria L.). The nature protection status of certain bird species is analyzed. 1 species listed in the Red book of Ukraine, 2 species In the red list of Kharkiv region. 2 types to the Washington Convention. Berne Convention Annex II (BC2) - 23 species, Berne Convention Annex III (BC3) - 13 species of birds, Bonn Convention Annex II (Bu2) - 10 species, Bonn Convention Annex I (BO1) - 2 species and 6 species of birds have no conservation status.

Keywords: forest belt; ornithomplexes; dendrophila; sclerotica; canofile

\section{До орнітофауни полезахисних лісосмуг Харківської області}

\author{
В. В. Пісоцька
}

Харківський наџіональний педагогічний університет імені Г. С. Сковороди, Харків, Украӥна 
Полезахисні лісосмуги - унікальні біоценози, де формуються специфічні орнітокомплекси, до яких входять птахи різних екологічних груп: перебувають та живляться синантропні види, птахи лісу і птахи полів. У ході проведених досліджень нами було зареєстровано 44 види птахів, які належать до 8 рядів: Falconiformes, Galliformes, Columbiformes, Cuculiformes, Upupiformes, Piciformes, Passeriformes, Ciconiiformes. Орнітофауна кленово-ясенових продувних лісосмуг представлена 39 видами птахів. Домінантними та субдомінантними є Ficedula albicollis Temm., Fringilla coelebs L. У мішаних продувних лісосмугах гніздяться 38 видів птахів, перебувають під час добування корму 2 види. Мішані щільні лісосмуги населяють 44 види птахів, біорізноманітність пов'язана 3 флористичним складом лісосмуги значною щільністю та добре сформованим підліском порівняно з іншими лісосмугами. Орнітофауна горобінієвих продувних лісосмуг представлена 26 видами птахів. Орнітокомплекс кленово-липових ажурних лісосмуг представлений 41 видом птахів.

Ключові слова: полезахисні лісосмуги; орнітокомплекси; дендрофіли; склерофіти; кампофіли

\section{Вступ}

Передумовою досліджень екологічних особливостей та ролі орнітофауни в агроландшафтах були агролісомеліоративні роботи, які активно проводили в Україні в другій половині XX ст. Більша частина польових досліджень була проведена у 50-70-х рр., коли проблемі штучних лісонасаджень приділяли значну увагу у зв'язку 3 пошуком шляхів підвищення врожайності сільськогосподарських культур (Budnichenko, 1968; Dementiev, 1949; Volchanetsky, 1969; Volchanetsky, 1952). Дослідники винайшли деякі практичні регіональні рекомендації щодо формування агроценозу з урахуванням необхідності рівномірного розподілу птахів на сільгоспугіддях (Kuzmenko T., Kuzmenko Yu., 2010).

Роботи зі створення полезахисних лісосмуг у Харківській області почалися ще в 50-ті роки минулого сторіччя. Майже за півстоліття полезахисні лісосмуги перетворилися в помітний елемент місцевого ландшафту, який сприяє заселенню відповідної фауни. Рослини, що утворюють лісосмуги, створюють безперервний рослинний покрив, впливають на навколишнє середовище і формують у ній місцеперебування інших живих організмів, тварин, грибів, мікроорганізмів.

Екологічні умови формування орнітокомплексів полезахисних лісосмуг України різні. До основних екологічних факторів, які впливають на формування орнітокомплексів полезахисних лісосмуг, можна віднести такі. По-перше, вікова структура насаджень, що має важливу роль. Заселення птахами полезахисних лісонасаджень відбувалося поступово, в міру зростання дерев і зміни ценотичних умов у них - від відкритих місцеперебувань у перші роки існування лісосмуг до клімаксних стадій сформованих біоценозів. Значення видового складу насаджень для птахів оцінювалося виключно лише відносно їх використання птахами для будівництва гнізд (Averin, 1910; Belik, 2009). Зв'язки формуються зазвичай опосередковано: через дію порідедифікаторів лісонасаджень, зокрема на ї захисні властивості і на кормову базу птахів (Volchanetsky, 1969; Volchanetsky, Medvedev, 1952; Budnichenko, 1968; Dementiev, 1949 ).

Дослідження орнітофауни полезахисних лісосмуг розпочалося в 50-60 pp. XX ст. За цей час отримано та опрацьовано значну кількість інформації щодо видового складу, щільності, біотопічного розподілу птахів лісосмуг, a також значення орнітокомплексів лісосмуг для сільськогосподарського виробництва. В Україні ці дослідження інтенсивно проводили в степовій зоні України. Це відображено в роботах А. А. Силантьєва, Л. Л. Семаго, І. Б. Волчанецького, О. С. Будниченка, О. М. Мельниченка та ін. (Budnichenko,1960; Budnichenko, 1968; Bulakhov, 2015; Bulakhov, Gubkin, Pakhomov, 2008; Dementiev, 1949; Volchanetsky, 1969; Volchanetsky, Medvedev, 1952; Lisetsky, 1976). Вивчено видовий склад птахів залежно від віку лісосмуг та їх структури, показано шляхи його формування, детально вивчено живлення птахів полезахисних лісосмуг та показано значення птахів для сільськогосподарського виробництва (Lisetsky, 1976).
У кінці XX століття та на початку XXI століття на склад орнітофауни східної частини України почали різко впливати непрямі антропогенні чинники: поява селітебних ландшафтів, забруднення навколишнього середовища, нерегульоване полювання, вирубка лісосмуг місцевим населенням та пожежі, порушення технології вирощування сільськогосподарських культур - все це згодом вплинуло на видовий склад орнітокомплеку полезахисних лісосмуг (Volchanetsky, 1969; Volchanetsky, Medvedev, 1952; Volchanetsky, 1969; Volchanetsky, 1950; Koshelev, 2011; Lisetsky, 1976; Kuzmenko, Kuzmenko, 2010).

Відомості, що стосуються видового складу орнітофауни полезахисних лісосмуг, $є$ застарілими, потребують уточнення та детального вивчення. Враховуючи вищезазначене, дослідження видового складу птахів полезахисних лісосмуг $є$ актуальним та доцільним.

\section{Матеріали та методи досліджень}

Мета проведених досліджень - вивчення особливостей формування орнітокомплексів (вивчення видового складу, екологічних груп птахів) полезахисних лісосмуг в територіальних межах Харківської області. Дослідження орнітофауни штучних полезахисних смуг проводились протягом 2013-2018 років на території Куп'янського, Двурічанського, Борівського, Шевченківського районів Харківської області. Маршрутні обліки птахів здійснювалися у гніздовий період з 01.04 по 30.06 за загальноприйнятою методико (Ravkin, Chelintsev, 1990). Протягом репродуктивного періоду гніздові території птахів виявляли як по голосу, так і за візуальними зустрічами окремих особин. Обліки проводили, як правило, у гніздовий період через 1,52 години після світанку. Щорічно проводили 2-3 обліки в кожному біотопі. Загальна протяжність маршруту становила 30 км. Кожного співаючого самця вважали за пару. На маршруті реєстрували всіх особин без урахування відстані до них, що обумовлено невеликою шириною лісосмуг, більшість з яких мають 3-4 ряди насаджень та ширину 20 м, зрідка - до 30 м, що робить можливим облік усіх птахів.

\section{Результати та їх обговорення}

У ході проведених досліджень нами було зареєстровано 44 види птахів, які належать до 8 рядів: Falconiformes, Galliformes, Columbiformes, Cuculiformes, Upupiformes, Piciformes, Passeriformes, Ciconiiformes. Кількість видів менша порівняно $з$ лісосмугами на території Лівобережного лісостепу, де на гніздуванні зареєстровано 51 вид птахів. Це представники таких рядів: Соколоподібні - 4 види (8 \% від загальної кількості видів), Куроподібні - 1 вид (2\%), Голубоподібні - 2 види (4 \%), Зозулеподібні - 1 вид (2\%), Совоподібні - 1 вид (2\%), Одудоподібні - 1 вид (2\%), Дятлоподібні - 5 видів (10\%), Горобцеподібні - 36 видів (71 \%) (Kuzmenko, Kuzmenko, Sagaidak, 2013).

Аналізуючи характер перебування видів на території дослідження, можна стверджувати, що 29 видів (65,9 \%) гніздові, 2 види $(4,5 \%)$, можливо, гніздяться на даній території, 9 видів (20,5\%) осілих та 4 види $(9,1 \%)$ перебувають під час добування корму (табл. 1). 
Таблиця 1

Видовий склад та особливості екологічного розміщення птахів полезахисних лісосмуг (Пісоцька, 2018)

\begin{tabular}{|c|c|c|c|c|c|c|}
\hline $\begin{array}{l}\text { № } \\
\Pi / \Pi\end{array}$ & Назва виду & $\begin{array}{c}\text { Характер } \\
\text { перебування }\end{array}$ & $\begin{array}{l}\text { Екологічна } \\
\text { група }\end{array}$ & $\begin{array}{c}\text { Відносна } \\
\text { чисельність } \\
\text { (за В. Бєліком) }\end{array}$ & $\begin{array}{c}\text { Тип } \\
\text { гніздування }\end{array}$ & $\begin{array}{l}\text { Охоронна } \\
\text { категорія* }\end{array}$ \\
\hline 1 & Ciconia ciconia $\mathrm{L}$. & Перебуває & Дендрофіл & $\mathrm{C}$ & Ac & Бк2,Бо2 \\
\hline 2 & Milvus migrans Bod. & Перебуває & Дендрофіл & $\mathrm{P}$ & Кр & $\begin{array}{c}\text { Бк } 2 ; \\
\text { Бо1,2;В2;ЧКУ;Х }\end{array}$ \\
\hline 3 & Buteo buteo L. & Перебуває & Дендрофіл & PPP & Kр & Бк $2 ;$ Бо 1,$2 ; \mathrm{B} 2$ \\
\hline 4 & Phasianus colchicus L. & Гніздовий & Кампофіл & $\mathrm{C}$ & $\mathrm{H}$ & Бк2 \\
\hline 5 & Columba palumbus L. & Гніздовий & Дендрофіл & $\mathrm{C}$ & Кр & - \\
\hline 6 & Streptopelia turtur L. & Гніздовий & Дендрофіл & $\mathrm{C}$ & Кр & Бк3 \\
\hline 7 & Cuculus canorus L. & Гніздовий & Дендрофіл & $\mathrm{CC}$ & Kр & Бк3 \\
\hline 8 & Asio otus $\mathrm{L}$. & Осілий & Дендрофіл & $\mathrm{C}$ & Кр & Бк2;В2 \\
\hline 9 & Apus apus L. & Гніздовий & Дендрофіл & $\mathrm{CC}$ & Kр & Бк3 \\
\hline 10 & Upupa epops $\mathrm{L}$. & Гніздовий & Дендрофіл & $\mathrm{C}$ & Kр & Бо 2 \\
\hline 11 & Jynx torquilla $\mathrm{L}$. & Гніздовий & Дендрофіл & $\mathrm{CC}$ & Kр & Бк2 \\
\hline 12 & Dendrocopos major L. & Осілий & Дендрофіл & $\mathrm{CC}$ & Д & Бк2 \\
\hline 13 & Hirundo rustica L. & Перебуває & Склерофіл & $\mathrm{CC}$ & Ac & Бк2 \\
\hline 14 & Motacilla alba L. & Гніздовий & Кампофіл & $\mathrm{CCC}$ & $\mathrm{H}$ & Бк2 \\
\hline 15 & Lanius collurio L. & Гніздовий & Дендрофіл & $\mathrm{CCC}$ & Kр & Бк2 \\
\hline 16 & Lanius minor L. & Гніздовий & Дендрофіл & $\mathrm{C}$ & Kр & Бк2 \\
\hline 17 & Sturnus vulgaris L. & Гніздовий & Дендрофіл & $\mathrm{C}$ & Kр & - \\
\hline 18 & Garrulus glandarius L. & Осілий & Дендрофіл & $\mathrm{CC}$ & Kр & - \\
\hline 19 & Pica pica L. & Осілий & Дендрофіл & $\mathrm{CCC}$ & Kр & - \\
\hline 20 & Corvus cornix $\mathrm{L}$. & Осілий & Дендрофіл & $\mathrm{CCC}$ & Kp & - \\
\hline 21 & Hippolais icterina $\mathrm{L}$. & $\begin{array}{l}\text { Можливо } \\
\text { гніздовий }\end{array}$ & Дендрофіл & PPP & Пр-ч & Бк2 \\
\hline 22 & Ficedula albicollis Temm. & Гніздовий & Дендрофіл & $\mathrm{CCC}$ & Д & Бк3,Бо2 \\
\hline 23 & Ficedula parva Pallas & Гніздовий & Дендрофіл & $\mathrm{CC}$ & Д & Бк 3, Бо2 \\
\hline 24 & Saxicola rubetra L. & Гніздовий & Кампофіл & $\mathrm{C}$ & $\mathrm{H}$ & Бк 3, Бо2 \\
\hline 25 & Erithacus rubecula L. & Гніздовий & Дендрофіл & $\mathrm{C}$ & Кр & Бк3,Бо2 \\
\hline 26 & Luscinia luscinia $\mathrm{L}$. & Гніздовий & Дендрофіл & $\mathrm{CCC}$ & $\mathrm{H}$ & Бк3,Бо2 \\
\hline 27 & Turdus merula L. & Гніздовий & Дендрофіл & $\mathrm{CC}$ & Kp & Бк3;Бо2 \\
\hline 28 & Turdus philomelos Brehm. & Гніздовий & Дендрофіл & $\mathrm{CCC}$ & Kр & Бк3;Бо2 \\
\hline 29 & Emberiza calandra L. & Гніздовий & Дендрофіл & $\mathrm{CC}$ & $\mathrm{H}$ & $X$ \\
\hline 30 & Sitta europaea L. & Осілий & Дендрофіл & $\mathrm{CC}$ & Д & Бк2 \\
\hline 31 & Passer domesticus L. & Осілий & Дендрофіл & $\mathrm{CC}$ & Ac & - \\
\hline 32 & Passer montanus L. & Осілий & Дендрофіл & $\mathrm{CCC}$ & Ac & Бк3 \\
\hline 33 & Fringilla coelebs L. & Гніздовий & Дендрофіл & $\mathrm{CCC}$ & Kp & Бк3 \\
\hline 34 & Chloris chloris L. & Гніздовий & Дендрофіл & $\mathrm{CCC}$ & Kр & Бк2 \\
\hline 35 & Carduelis carduelis L. & Гніздовий & Дендрофіл & $\mathrm{CCC}$ & Kp & Бк2 \\
\hline 36 & Turdus pilaris L. & Гніздовий & Дендрофіл & $\mathrm{P}$ & Kp & Бк3;Бо2 \\
\hline 37 & Sylvia nisoria $\mathrm{L}$. & $\begin{array}{l}\text { Можливо } \\
\text { гніздовий }\end{array}$ & Дендрофіл & PPP & Кр & Бк2 \\
\hline 38 & Emberiza citrinella L. & Гніздовий & Кампофіл & $\mathrm{CC}$ & $\mathrm{H}$ & Бк2 \\
\hline 39 & Apus apus L. & Гніздовий & Дендрофіл & $\mathrm{CC}$ & Kр & Бк2 \\
\hline 40 & Anthus campestris L. & Гніздовий & Дендрофіл & $\mathrm{C}$ & Kр & Бк2 \\
\hline 41 & Oriolus oriolus L. & Гніздовий & Дендрофіл & $\mathrm{CC}$ & Kр & Бк2 \\
\hline 42 & Sylvia atricapilla L. & Гніздовий & Дендрофіл & $\mathrm{C}$ & Kp & Бк2 \\
\hline 43 & Parus major L. & Осілий & Дендрофіл & $\mathrm{CCC}$ & Д & Бк2 \\
\hline 44 & Parus caeruleus L. & Гніздовий & Дендрофіл & $\mathrm{C}$ & Д & Бк2 \\
\hline
\end{tabular}

* Охоронні категорії: Бернська конвенція, додаток II (Бк2); Бернська конвенція, додаток ІІІ (Бк3); Боннська конвенція, додаток II (Бо2); Боннська конвенція, додаток I (Бо1); Вашингтонська конвенція (В); Червона книга України (ЧКУ); Червона книга Харківської області (X).

Визначено тип гніздування зареєстрованих видів: кроневі - 27 видів, де переважають зяблик (Fringilla coelebs L.), зеленяк (Chloris chloris L.); наземногнізні 6 видів: вівсянка звичайна (Emberiza citrinella L.), просянка (Emberiza calandra L.), соловейко східний (Luscinia luscinia L.), фазан (Phasianus colchicus L.); дуплогнізні - 6 видів: повзик (Sitta europaea L.), синиця велика (Parus major L.), синиця блакитна (Parus caeruleus), мухоловка білошийка (Ficedula albicollis Temm.); приземно-чагарникові - 1 вид берестянка звичайна (Hippolais icterina L.); антропогенні спорудження - 4 види (горобець польовий Passer montanus L.), горобець хатній (Passer domesticus L.), ластівка сільська (Hirundo rustica L.), лелека білий (Ciconia ciconia L.).
Розподіл птахів за екологічними групами: дендрофіли 39 видів (88,7\%), а саме зяблик, зеленяк (Chloris chloris L.), одуд, вивільга (Oriolus oriolus L. ) та інші; кампофіли 4 види $(9,2 \%)$ - вівсянка звичайна (Emberiza citrinella L.), трав'янка лучна (Saxicola rubetra L. ), фазан (Phasianus colchicus L.) та 1 вид - 2,2 \% склерофіл - ластівка сільська (Pesotskaya, 2018).

Визначено відносну чисельність зареєстрованих видів за запронованою класифікацією В. П. Бєліка: найбільш чисельними є зяблик, зеленяк, щиглик (Carduelis carduelis L.), співочий дрізд (Turdus philomelos Brehm.), сорокопуд терновий (Lanius collurio L.), соловейко східний (Luscinia luscinia L), сорока (Pica pica L.), ворона сіра (Corvus cornix L.). 
Рідкісними видами є берестянка звичайна (Hippolais icterina L.), канюк звичайний (Buteo buteo L.), кропив'янка рябогруда (Sylvia nisoria L.) (Belik, 2018).

Проаналізовано природоохоронний статус визначених видів птахів: 1 вид занесений до Червоної книги України, 2 види - до Червоного списку Харківської області, 2 види до Вашингтонської конвенції, до Бернської конвенції (додаток II (Бк2) - 23 види, Бернської конвенції (додаток III (Бк3) - 13 видів птахів, Боннської конвенції, додаток II (Бо2) - 10 видів, Боннської конвенції (додаток I (Бо1) 2 види. 6 видів птахів не мають природоохоронного статусу (табл. 1) (Pesotskaya, Chaplygin, 2018).

До основних факторів, які впливають на формування орнітокомплексів полезахисних лісосмуг, належать:
1. Фітоценотичний склад лісосмуг. Видовий склад рослин лісосмуги має важливе значення для місць гніздування та кормової бази птахів.

Деревостан обраних модельних лісосмуг формують 25 видів дерев та 15 видів кущів; більшість 3 них мають мішаний видовий склад деревостану i підліску, неоднорідну структуру, порослеву генерацію, проміжки, прогалини та вирубки, велику кількість всихаючих та дуплистих дерев (табл. 2).

Орнітофауна кленово-ясенових продувних лісосмуг представлена 39 видами птахів. Домінантами та субдомінантами $€$ Ficedula albicollis Temm., Fringilla coelebs L.

У мішаних продувних лісосмугах гніздяться 38 видів птахів та перебувають під час добування корму 2 види.

Таблиця 2

Особливості формування орнітокомплексів різних за фітоценотичним складом лісосмуг (Пісоцька, 2018)

\begin{tabular}{|c|c|c|c|c|c|c|}
\hline $\begin{array}{l}\text { № } \\
\Pi / \Pi\end{array}$ & Назва виду & $\begin{array}{c}\text { Кленово- } \\
\text { ясенові } \\
\text { продувні } \\
\text { лісосмуги } \\
\text { (Кяпл) }\end{array}$ & $\begin{array}{c}\text { Мішані } \\
\text { продувні } \\
\text { лісосмуги } \\
\text { (Мпл) }\end{array}$ & $\begin{array}{c}\text { Мішані } \\
\text { щільні } \\
\text { лісосмуги } \\
\text { (Мщл) }\end{array}$ & $\begin{array}{c}\text { Горобінієві } \\
\text { продувні } \\
\text { лісосмуги } \\
\text { (Гпл) }\end{array}$ & $\begin{array}{c}\text { Кленово- } \\
\text { липові } \\
\text { ажурні } \\
\text { лісосмуги } \\
\text { (К-лал) }\end{array}$ \\
\hline 1 & Ciconia ciconia $\mathrm{L}$. & + & + & + & - & + \\
\hline 2 & Milvus migrans Bod. & - & - & + & - & - \\
\hline 3 & Buteo buteo L. & - & + & + & - & + \\
\hline 4 & Phasianus colchicus L. & + & + & + & - & - \\
\hline 5 & Columba palumbus L. & + & + & + & + & + \\
\hline 6 & Streptopelia turtur L. & + & + & + & + & + \\
\hline 7 & Cuculus canorus L. & + & + & + & - & + \\
\hline 8 & Asio otus L. & + & + & + & - & + \\
\hline 9 & Apus apus L. & + & + & + & + & + \\
\hline 10 & Upupa epops $\mathrm{L}$. & + & + & + & + & + \\
\hline 11 & Jynx torquilla $\mathrm{L}$. & + & + & + & + & + \\
\hline 12 & Dendrocopos major L. & + & + & + & - & + \\
\hline 13 & Hirundo rustica L. & - & + & + & - & + \\
\hline 14 & Motacilla alba L. & + & + & + & + & + \\
\hline 15 & Lanius collurio L. & + & + & + & - & + \\
\hline 16 & Lanius minor L. & + & + & + & + & + \\
\hline 17 & Sturnus vulgaris L. & - & - & + & + & + \\
\hline 18 & Garrulus glandarius L. & + & + & + & + & + \\
\hline 19 & Pica pica $\mathrm{L}$. & + & + & + & + & + \\
\hline 20 & Corvus cornix L. & + & + & + & + & + \\
\hline 21 & Hippolais icterina L. & + & + & + & + & + \\
\hline 22 & Ficedula albicollis Temm. & + & + & + & + & + \\
\hline 23 & $\begin{array}{l}\text { Ficedula parva Sibley and } \\
\text { Monroe }\end{array}$ & + & + & + & - & + \\
\hline 24 & Saxicola rubetra $\mathrm{L}$. & + & + & + & - & + \\
\hline 25 & Erithacus rubecula L. & + & + & + & + & + \\
\hline 26 & Luscinia luscinia $\mathrm{L}$. & + & + & + & + & + \\
\hline 27 & Turdus merula L. & + & + & + & + & + \\
\hline 28 & Turdus philomelos Brehm. & + & + & + & - & + \\
\hline 29 & Emberiza calandra L. & + & + & + & + & + \\
\hline 30 & Sitta europaea L. & + & - & + & + & + \\
\hline 31 & Passer domesticus L. & + & + & + & + & + \\
\hline 32 & Passer montanus L. & + & + & + & + & + \\
\hline 33 & Fringilla coelebs L. & + & + & + & + & - \\
\hline 34 & Chloris chloris L. & + & + & + & - & + \\
\hline 35 & Turdus pilaris L. & + & + & + & - & + \\
\hline 36 & Sylvia nisoria $\mathrm{L}$. & + & + & + & + & + \\
\hline 37 & Emberiza citrinella L. & + & + & + & + & + \\
\hline 38 & Apus apus L. & + & + & + & + & + \\
\hline 39 & Anthus campestris L. & + & + & + & - & + \\
\hline 40 & Oriolus oriolus L. & + & + & + & - & + \\
\hline 41 & Sylvia atricapilla $\mathrm{L}$. & + & + & + & - & + \\
\hline 42 & Carduelis carduelis L. & + & + & + & + & + \\
\hline 43 & Parus major L. & + & + & + & + & + \\
\hline 44 & Parus caeruleus L. & - & - & + & - & + \\
\hline
\end{tabular}


Мішані щільні лісосмуги населяють 44 види птахів, така біорізноманітність пов'язана 3 флористичним складом лісосмуги, значною щільністю та добре сформованим підліском порівняно з іншими лісосмугами.

Орнітофауна горобінієвих продувних лісосмуг представлена 26 видами птахів, незначне біорізноманіття птахів пов'язане 3 бідним фітоценотичним складом лісосмуги, що свідчить про значний вплив на біорізноманіття фітоценотичного складу лісосмуг. Орнітокомплекс кленово-липових ажурних лісосмуг представлений 41 видом птахів.

Аналізуючи індекс подібності біорізноманіття різних типів лісосмуг (табл. 3), можна стверджувати, що найбільш подібними, за видовим складом птахів, між собою є мішані щільні лісосмуги і кленово-липові ажурні лісосмуги (індекс Жаккара - 93,1 та індекс Серенсена - 96,4) та кленово-ясенові продувні лісосмуги 3 мішаними продувними лісосмугами (індекс Жаккара - 92,6 та індекс Серенсена - 96,2).

2. Вікова структура насаджень має важливу роль. Заселення птахами полезахисних лісонасаджень відбувалося поступово, у міру зростання дерев і зміни ценотичних умов в них - від відкритих місцеперебувань у перші роки існування лісосмуг до клімаксних стадій сформованих біоценозів. Значення видового складу насаджень для птахів оцінювали виключно лише відносно їх використання птахами для будівництва гнізд (Belik, 2009; Dementiev, 1949).

\section{Таблиця 3}

Подібність біорізноманіття птахів у різних типах лісосмуг

\begin{tabular}{ccccc}
\hline $\begin{array}{c}\text { № } \\
\text { п/п }\end{array}$ & $\begin{array}{c}\text { Пара модельних } \\
\text { ділянок }\end{array}$ & $\begin{array}{c}\text { Кількість видів } \\
\text { загальних }\end{array}$ & Індекс подібності \\
\hline 1 & Кяпл - Мщл & 39 & 88,6 & 93,9 \\
2 & Кяпл - Гпл & 25 & 62,5 & 76,9 \\
3 & Кяпл - Клал & 37 & 86,0 & 92,5 \\
4 & Кяпл - Мпл & 38 & 92,6 & 96,2 \\
5 & Мпл - Мщл & 40 & 90,9 & 95,2 \\
6 & Мпл - Клал & 38 & 83,3 & 74,2 \\
7 & Мщл - Гпл & 26 & 59,0 & 74,6 \\
8 & Гпл - Клал & 25 & 59,5 & 72,2 \\
9 & Мпл - Гпл & 24 & 60 & 96,4 \\
\hline
\end{tabular}

Аналізуючи особливості досліджуваних полезахисних лісосмуг Харківської області, слід сказати, що більшість 3 них $\epsilon$ середньовіковими (віком 20-30 років) та старовіковими (вік більше 50 років). Більшість досліджуваних лісосмуг зазнала значного антропогенного впливу, що пов'язано з незаконними вирубками.

\section{Висновки}

1. Гніздова орнітофауна полезахисних лісосмуг Харківської області налічує 44 види птахів 38 рядів 3 переважанням представників ряду Горобцеподібні.

2. Орнітофауна кленово-ясенових продувних лісосмуг представлена 39 видами птахів. Домінантними та субдомінантними є Ficedula albicollis Temm., Fringilla coelebs L. У мішаних продувних лісосмугах гніздяться 38 видів птахів, перебувають під час добування корму 2 види. Мішані щільні лісосмуги населяють 44 види птахів, біорізноманітність пов'язана 3 флористичним складом лісосмуги, значною щільністю та добре сформованим підліском порівняно з іншими лісосмугами. Орнітофауна горобінієвих продувних лісосмуг представлена 26 видами птахів. Орнітокомплекс кленово-липових ажурних лісосмуг представлений 41 видом птахів.

3. Аналізуючи особливості формування орнітофауни полезахисних лісосмуг, можна стверджувати, що в даних біотопах мешкають птахи різних екологічних груп, біотопів, перебувають та живляться синантропні види, птахи лісу, птахи полів, що здатні сформувати унікальні біотопи. Тому полезахисні лісосмуги - комбіновані комплексні біогеоценози.

\section{References}

Averin, V. G. (1910). K ornitologii Harkovskoj gubernii [To the ornithology of the Kharkov province] Trudy Obshchestvava ispytatelej prirody pri Harkovskom universitete (in Russian).
Belik, V. P. (2009). Pticy iskusstvennyh lesov stepnogo Predkavkazya [Birds artificial forests of the steppe Ciscaucasia]. Krivoj Rog (in Russian).

Budnichenko, A. C. (1960). Ob ekologo-geograficheskih zakonomernostyah $\mathrm{v}$ formirovanii fauny ptic iskusstvennyh lesonasazhdenij stepnoj zony Ukrainy [On ecological and geographical patterns in the formation of bird fauna of artificial forest plantations of the steppe zone of Ukraine]. Byull. MOIP. Otd. biol. 1, 65, 3, 37-45 (in Russian).

Budnichenko, A. S. (1968). Pticy iskusstvennyh lesonasazhdenij stepnogo landshafta $\mathrm{i}$ ih pitanie [Birds of artificial forest plantations of the steppe landscape and their food]. Voronezh (in Russian).

Bulakhov, V. L, Gubkin, A. A, Ponomarenko, O. L., Paxomov, O. Ye. (2015) Biologichne riznomanittya Ukrayiny`. Ptaxy`: Negorobcepodibni (Passeriformes) [Biological diversity of Ukraine. Dnepropetrovsk region. Sparrow-like]. Dnipropetrovsk (in Ukrainian).

Bulakhov, V. L., Gubkin, A. A, Ponomarenko, O. L., Paxomov, O. Ye. (2008). Biologichne riznomanittya Ukrayiny`. Ptakhy: Gorobcepodibni [Aves: Passeriformes).[Biological diversity of Ukraine. Dnepropetrovsk region. Birds are Not perching birds]. Dnipropetrovsk (in Ukrainian).

Dementev, G. P. (1949). Nekotorye ekologicheskie problemy, svyazannye $\mathrm{S}$ zaseleniem pticami polezashchitnyh lesonasazhdenij [Some environmental problems associated with the settlement of protected forest plantations by birds]. Zool. zhurn. Sankt-Peterburg. 4, 307-316 (in Russian).

Koshelev, V. O. (2011). Ekologichni umovi formuvanya ornitokompleksiv polezahisnih lisosmug pivdnya Zaporizkoï oblasti [Ecological conditions of formation of ornithocomplexes of protective forest belts in the South of Zaporizhzhya region.]. Ukrainian Journal of Ecology (in Ukrainian).

Kuzmenko, T. M., Kuzmenko, Yu. V. (2010). Gnizdova ornitofauna lisosmug Livoberezhnogo Lisostepu [The 
breeding avifauna of wooded left-Bank forest-Steppe]. Branta: Sbornik trudov Azovo-Chernomorskoj ornitologicheskoj stancii, 13 (in Ukrainian).

Kuzmenko, T. M., Kuzmenko, Yu. V. (2013). Ridkisni vidi ptahiv agrolandshaftiv Polissya ta Lisostepu Livoberezhnoï Ukraïni [Rare species of birds of agricultural landscapes of Polissya and forest-Steppe of left-Bank Ukraine]. Sbornik trudov Azovo-Chernomorskoj ornitologicheskoj stancii, 16, 63-74 (in Ukrainian).

Liseckij, A. S. (1976). O nekotoryh osobennostyah gnezdyashchejsya ornitofauny drevesnyh nasazhdenij [On some peculiarities of the breeding avifauna of trees]. Vestnik Harkivskokho un-ta, problemy ontogeneza i bioekologii zhivotnyh, 135, 125-127 (in Ukrainian).

Pisocka, V. V., Chapligina, A. B. (2018). Osoblivosti formuvannya ornitokompleksiv polezahisnih lisosmug (na prikladi Harkivskoï oblasti). [Features of formation of ornithocomplexes of protective forest belts (on the example of Kharkiv region]. Ekologichni doslidzhennya $\mathrm{u}$ vishchih navchalnih zakladah. Herson (in Ukrainian).
Ravkin, E. S., Chelincev, N. G. (1990). Metodicheskie rekomendacii po kompleksnomu marshrutnomu uchetu ptic [Methodical recommendations on complex route accounting of birds]. VNII priroda Goskomprirody SSSR, 33 (in Russian).

Volchaneckij, I. B. (1952). O formirovanii fauny ptic i mlekopitayushchih molodyh polezashchitnyh polos $\mathrm{v}$ zasushlivyh rajonah levoberezhya Ukrainy [On the formation of the fauna of birds and mammals of young windbreaks in the arid regions of the left Bank of Ukraine]. Trudy NII biologii pri HGU. 7-25 (in Russian).

Volchaneckij, I. B. (1969). Ocherednye zadachi izucheniya ptic iskusstvennyh nasazhdenij [The next task of the study of birds artificial plantations]. Izuchenie resursov nazemn. pozvonochnyh fauny Ukrainy. Kiev. 27-29 (in Russian).

Volchaneckij, I. B., Medvedev, S. I. (1950). K voprosu o formirovanii fauny polezashchitnyh polos [On the question of the formation of the fauna of protective bands]. Trudy NII biologii pri HGU. 7-28 (in Russian). 